\title{
Animals in Walden
}

\author{
Qin Liu $^{1}$ \\ ${ }^{1}$ School of Foreign Language, Yancheng Normal University, Yancheng, China \\ Correspondence: Qin Liu, School of Foreign Language, Yancheng Normal University, Yancheng, China. E-mail: \\ hobbyc@163.com
}

Received: July 14, 2017 Accepted: August 3, 2017 Online Published: August 9, 2017

doi:10.5539/ells.v7n3p43 URL: http://doi.org/10.5539/ells.v7n3p43

\begin{abstract}
Henry David Thoreau is a great American writer of transcendentalism and the pioneer of modern environmentalism. Being an ardent lover of nature, he devoted his entire life to studying the relationship between man and nature, and bequeathed a legacy of works in this field. He believed that nature was the symbol of spirit, and had a far-reaching influence on man and his character, and human beings should live harmoniously with nature for the long sustainable development. In Walden which is his masterpiece He endows the animals with human characteristics. Thereupon, Thoreau often describes the similarities between animals and people he comes across. People can be just as greedy and shallow as the marmot of the prairie, or as naughty and clumsy as red squirrels, or as lazy and cunning as chickadees, or as loyal as gundogs in Thoreau's writings. Thoreau spent two years living a simple life at Walden on his own. He recounted in details the living habits of these animals, from woodchucks, loons to mice and hawks.
\end{abstract}

Keywords: Walden, Henry David Thoreau, animal

\section{Introduction}

A proponent of transcendentalism, Henry David Thoreau is regarded as an outstanding and influential American writer. He is also the first major interpreter of nature in American literary history. However, in his own days, he was viewed as an insignificant eccentric writer and one who had "stolen all his apples from Emerson's orchard" (Harding, p. 1). In the eyes of his contemporaries, he was only known to be a faithful disciple of Ralph Waldo Emerson. Nevertheless, centuries after his death, his lifelong devotion to nature and mankind has made himself a cultural icon for modern Americans, and even the whole world. Not surprisingly, his masterpiece Walden ranks the first among the ten books which have shaped the American character. It has been regarded as the "Green Bible" in the literary history of America (Buell, p. 30).

Thoreau was born in 1817 in Concord, Massachusetts. He lived in the time when business and technology governed the life of Americans. Although Concord was a small town, it was one of the cultural centers at that time. Thoreau spent almost all his life living there, and he was deeply upset that his hometown had been deeply influenced by industrialism. He noticed that the natural bond between man and nature had been destroyed by man's excessive exploitation of nature (Armstrong, p. 20). More importantly, the process of industrialism had destroyed the natural resources and the native culture. He believed that nature was the symbol of spirit, and had a far-reaching influence on man and his character, and human beings should live harmoniously with nature for the long sustainable development.

Thoreau devoted his whole life to understanding nature. During his short life of 44 years, he kept recording nature and left a legacy of works. He is a fruitful writer whose writings include prose, essays, journals, and poetry which amount to over 20 volumes. Among these, two works stand out as the most influential: one is Walden, which reflects his philosophical thinking about the relationship between man and nature; and the other is Civil Disobedience, which constitutes his argument on non-violent individual resistance to an unjust government to have the harmony in the society. These writings reveal his firm belief that human beings can achieve an ideal state of harmony in the nature and society through great efforts.

Thoreau spent two years living a simple life at Walden on his own. During that time, he had very few visitors, and the only frequent companions he had were the animals at Walden Pond. He devoted great attention and affection to these non-human friends, with whom he shared the woods. He recounted in details the living habits of these animals, from woodchucks, loons to mice and hawks. 


\section{Literature Review}

Thoreau is a very controversial writer in the history of American literature. In his own time, he was not universally accepted and was even severely criticized by his contemporaries. American writer J.R. Lowell and the British writer A. E. Stevenson despised him as a wild idler (Buell, p. 70). Even his solitary living at Walden was judged as womanish behavior and something unmanly by Scottish author Robert Louis Stevenson. The idea of equality with other living organism was translated by John Greenleaf Whittier, a poet, as human beings being reduced to animals and walk on four legs. Nevertheless, there were some early critics who praised his artistic achievement and his keen observation of nature (Campbell, p. 75). His friend Nathaniel Hawthorne once said "Mr. Thorow [Thoreau] is a keen and delicate observer of nature - a genuine observer, which, I suspect, is almost as rare a character as even an original poet; and Nature, in return for his love, seems to adopt him as her especial child, and shows him secrets which few others are allowed to witness." (Baym, p. 166)

Since the emergence of the environmental movement in the 1970s, Thoreau has been reinterpreted as a son of nature, for his works cover not only the description of the beauty of nature but also reveal his deep contemplation of human-nature relationship (Bunge, p. 124). The greatest turning point of the study on Thoreau took place in 1941 when F.O. Matthiessen of Harvard University published American Renaissance: Art and Expression in the Age of Emerson and Whitman. In the book, Walden was viewed as an organic whole, and Thoreau was regarded as a classical writer in American literature.

\section{Animals' Variety}

Walden is composed of 18 chapters, and almost each chapter has mentioned the flora and fauna of Walden. There are different kinds of animals and plants in Walden. Thoreau attaches much importance to the diversities of animals. He appreciates the richness of species of animals at Walden Pond for the reason that the diversity of life forms helps man to achieve self-culture. He advocates that people should give other living organisms enough space on the earth and human beings have no rights to destroy the diversity of nature. In Walden, Thoreau passionately observes various kinds of animals which make his life meaningful and conducive to self-culture (Furui, p. 330).

Thoreau enjoys his spiritual communion with nature through animals and the liveliness of the animals' world also gives Thoreau much pleasure. At the Walden Pond, the transformations of the seasons are analogized to the changes of a single day. The night is the winter to Thoreau; the epitomes of the spring and fall are the morning and evening, and the noon represents the summer to him. The diversities of animals accompany him day and night, from spring to winter. In the morning, cocks crow for him. At dusk, he could listen to the frogs cry. At night, birds sing songs to him. In winter, the whole world is frozen, but not the animals in Walden. In chapter 15 "Winter Animals", Thoreau gives a vivid description of animals in winter.

Here, foxes to Thoreau are like "burrowing men" still fighting for their survival (Thoreau, p. 228), waiting for the transformation. It can be inferred here that survival is not what we live for. What we should do is to attempt to find meaning in life and diversify our modes of living. Human beings also need a transformation in life.

Surprisingly, animals are quite active in the winter. Winter has silenced most of other living organisms but not the animals. Usually the red squirrel would wake Thoreau up in the dawn. In the twilight and the night, rabbits would come and accompany him to have a hearty meal. The red squirrel would come and go to entertain him. Thoreau was deeply fascinated by the dances of squirrels.

The jays, the chickadees in flocks all come to pick up the crumbs which Thoreau threw out of his house. They are not afraid of him, and "occasionally stepped upon my shoe". (Thoreau, p. 231)

With the arrival of spring, every living being come back to live. The whole universe wakes up, and so do the animals. In Chapter seventeen, Thoreau describes enthusiastically the vitality of animals in spring. In Walden, Thoreau is accompanied by a diversity of animals. They live in harmony with each other, and the various activities of animals gives Thoreau a new sense of the variety of the nature and the meanings of life. It can be said that the diversities of animals make a diverse mode of life. What Thoreau seeks is not to encourage people to live only one mode of life, but to wake his neighbors up in the morning like the chanticleer. Thoreau would not have people all give up their normal life to live in the woods. What Thoreau advocates is a diverse and harmonious life with nature, with humans and other living organisms included. The diversity of animals is one essential aspect of a diverse life. Thoreau himself would not live only one mode of life, which is the reason why he leaves the woods in the end. Naess also believes that "Life is a succession of different expeditions full of uncertainties and challenges. One stereotyped mode of life might incur spiritual stagnation and poverty."(Naess, p. 126) Hence, a diversity of life would promote the achievement of self-culture, and the modes of life should 
and could be as diverse as possible.

\section{Animals' Human Characteristics}

In Walden, Thoreau views birds and animals as equivalents to human beings. Man is "a part and parcel of nature". All kinds of animals are equal inhabitants of Walden just as he is. He regards these non-human lives as his neighbors, and endows them with human characteristics. In his writing, these animals are referred to with human pronouns, "he" or "she" rather than "it". In his vivid description of the snake, for example, Thoreau refers to it as "he" and endows it with human characteristics.

In Walden, Thoreau believes that diverse species of animals are equal parts of the ecosphere. The animals' world and the human world have a lot in common. Thoreau learns more about human beings by observing the human characteristics in animals.

Animals' world has its own tensions and conflicts as that of human beings, and only the fittest can survive. By closely observing the fight in the animals' world, we can have a better idea of human community. In the chapter of "Brute Neighbors", Thoreau recounts in details a savage war between a large black ant and a smaller red ant, and he deliberately describes the war between the red ants and the black ants as a civil war. He elevates the animal war into a noble human war, and endows the ants with human thoughts and emotions.

Thoreau pays great attention to its resemblance to human wars. The ants possess the human characteristics, and they are as fierce and courageous as human soldiers. The animals' world is not peaceful at all. Each has to fight for its survival, and the conflicts and tensions are everywhere. Only the strongest, smartest, fittest can win in the end. In the world of animals, each wants to dominate the others, once they get the dominant place, they will not let it go. Moreover, the animals cannot stop fighting all over their lives, and they are forced to live a struggling life all through their lives. Thoreau believes that the animals are fighting for a principle, a belief, just like our ancestors. They have to fight to have their essential needs satisfied. Similar to human community, animals have racial and national conflicts, and the world is also full of violence and conflicts.

Similar to human world, familial love exists in animal world. Although they have to fight for the survival, and the living conditions is bad, they are not cruel and indifferent to each other. They do not isolate themselves from other species; instead, they live in harmony with each other. The best example of love among animals is found in the paragraph in which Thoreau describes a shy partridge leading her brood past his windows.

We can easily tell that the partridge is the mother due to her behaviors. If you approach a little closer, the mother would call anxiously to signal the young to move away. She would try every means to attract your attention so as to make the young partridges safe. She is not aware of danger herself. The only thought she has is to save her children. What a great mother she is.

From the above analysis, we can see that nature is an organic whole which comprises both human and nonhuman organisms. The attribution of human characteristics to animals helps Thoreau to enrich and deepen his understanding of nature and the mankind (Simon, p. 251), for the reason that the natural laws embodied in the animals' activities can apply to humans as well. The close observation and persistent contemplation on the animals enables people to reap the harvest of self-culture which will be analyzed in the following chapters.

\section{Hawk in Walden}

Thoreau has a lot in common with animals he describes in Walden. They all live lonely and nobly at Walden Pond. Thoreau endows the hawk with unique signification. The similarities between Thoreau and the hawk are surprising.

On April 29, Thoreau heard a singular rattling sound when he was fishing from the bank of the river. He saw "the most ethereal flight" and had ever witnessed. He observed a graceful nighthawk soaring nobly and lonely into the sky.

Instead of showing sympathy for the hawk, Thoreau is deeply touched by its elegant loneliness (Seton, p. 21). In his eyes, it is not the unaccompanied hawk that is lonely but the earth which lies beneath the soaring hawk. In interpreting this scene from a new perspective, Thoreau projects his own thoughts and emotions onto the hawk. For most of his life, Thoreau lived a solitary life. He was never married, and thus like the hawk, he had no companions. He was lonely and unaccepted by the world when he was alive. His articles were refused or declined, but he did not give up his dream. He kept on flying just like the hawk. After years of hard work, he published A Week on Concord and Merrimack River and Walden, but these two books proved to be failures. They did not create good sales, few readers understood them - they were dismissed as rubbish. Even Emerson, his best friend, showed a deep misunderstanding of him in his eulogy to Thoreau. In Emerson's view, Thoreau 
had dissipated his talents and energy on trivial things, which was the reason why he had not been able to accomplish much in his lifetime.

It is not surprising that Thoreau was not accepted by his contemporaries. However, Thoreau continued in his own way, despite despises of other people. He was not lonely, but made the world lonely beneath his great achievements. He did not "soar" like literary giants, and achieve fame and wealth overnight. Nor did he waste his talents and live on as a common people. He kept on struggling and fighting without stop. "Mounting again and again with its strange chuckle" (Thoreau, p. 262), he did not laugh at the world, nor was laughed at. Instead he continued his free and noble pursuit, maybe he would suffer again and again, and he would recover and continue his life as if nothing had happened (Souls, p. 71). He has no companions, but he is free, he can transcend all bounds and limits, and be a great winter, leave the world a huge legacy.

For Thoreau, solitary living can help him be a self-reliant individual, solitude is essential for living an ecological way of life. At Walden Pond, Thoreau strives to listen to his own voices and live his own life, despite of the gossips and prejudices of the fellow citizens.

"If a man does not keep pace with his companions, perhaps it is because he hears a different drummer, let him step to the music which he hears, however measured or far away." (Thoreau, p. 278)

Living alone in nature, Thoreau is not lonely at all. He has found his own voices and marches to the sound of his own drummer like the hawk flying lonely and forcefully under the sky.

\section{Conclusion}

To Thoreau, animals are an indispensable part of nature. At Walden, he is a friendly neighbor of a diversity of animals which diversifies his mode of life. His close living with animal leads to his profound observation of human characteristics which helps him gain a deep understanding of human nature. His identification with the hawk declares his goal of life. From Thoreau's living experiences with animals, we can see that he has a belief that the respect for biocentric equality, a voluntary simplicity of life and self-culture through nature work together to form a harmonious society.

Based on the above analysis, we can conclude that Thoreau's ideas and explorations in Walden point out the way to a harmonious society. Thus it is worthwhile to reread Thoreau's Walden from the perspective of the relationship between animals and human beings, and to better grasp the essence of his philosophy.

\section{Acknowledgement}

This work is supported by Top-notch Academic Programs Project of Jiangsu Higher Education Institutions.

\section{References}

Armstrong, S. J., \& Botzler, R. G. (1993). Environmental ethics: divergence and convergence. Proceedings of the Edinburgh Mathematical Society, 18(4), 321-324.

Baym, N. (1985). The Norton Anthology of American Literature (2nd ed.). New York, London: W. W. Norton \& Company, Inc.

Buell \& Lawrence. (1998). The environmental imagination: Thoreau, nature writing, and the formation of American culture. Cambridge: Belknap Press of Harvard University Press.

Buell \& Lawrence. (1999). Thoreau and the Natural Environment. Cambridge: Cambridge University Press.

Bunge, N. (2017). Prairie gold: an anthology of the american heartland ed. by lance m. sacknoff, xavier cavazos, and stephanie brook trout (review). Middle West Review, 3.

Campbell, A., \& Campbell, J. (2016). Trails to walden pond: pragmatic aesthetics and relational aesthetics approach the examined life. Pluralist, 11, 1. https://doi.org/10.5406/pluralist.11.2.0001

Furui, Y. (2016). Networked solitude: walden, or life in modern communications. Texas Studies in Literature \& Language, 58, 329-351. https://doi.org/10.7560/TSLL58304

Harding, W. (1982). The Days of Henry Thoreau: A biography. New Jersey: Princeton University Press.

Naess, A. (1989). Ecology, Community and Lifestyle: outline of an Ecosophy (Trans. D. Rothenberg). Cambridge: Cambridge University Press. https://doi.org/10.1017/CBO9780511525599

Seton, E. T. (2007). Wild animals I have known; The trail of the Sandhill Stag. Athena Press.

Simon, K. (2016). Affect and cruelty in the atlantic system: the hauntological argument of henry david thoreau's cape cod. ESQ: A Journal of Nineteenth-Century American Literature and Culture, 62, 245-282. 
Souls, M. E. (1989). Ecology, community and lifestyle: outline of an ecosophy. Trends in Ecology \& Evolution, 4(10), 323-324. https://doi.org/10.1016/0169-5347(89)90047-5

Thoreau, H. D. (1972). Walden. Oregon State University Press, Princeton: Princeton University Press.

\section{Copyrights}

Copyright for this article is retained by the author, with first publication rights granted to the journal.

This is an open-access article distributed under the terms and conditions of the Creative Commons Attribution license (http://creativecommons.org/licenses/by/4.0/). 